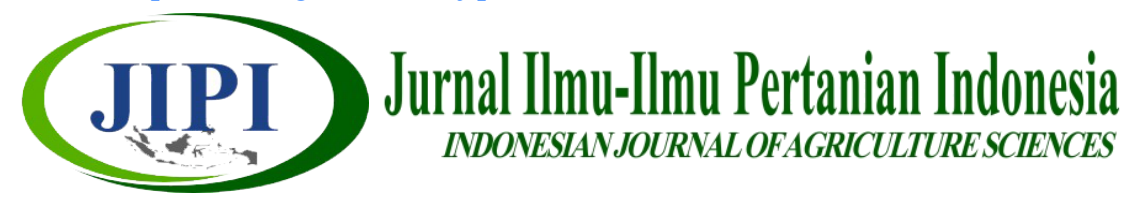

\title{
RESPON PERTUMBUHAN STEK BATANG TANAMAN BUAH NAGA MERAH (Hylocereus costaricensis) TERHADAP KONSENTRASI DAN LAMA PERENDAMAN AIR KELAPA MUDA
}

\author{
Azis Febrianto ${ }^{1}$, Hermansyah ${ }^{1^{*}}$, Faiz Barchia ${ }^{2}$ \\ ${ }^{1}$ Program Studi Agroekoteknologi, Fakultas Pertanian Universitas Bengkulu \\ ${ }^{1}$ Program Studi Ilmu Tanah, Fakultas Pertanian Universitas Bengkulu \\ * Corresponding Author : hermansyah@unib.ac.id
}

\begin{abstract}
[GROWTH OF DRAGON FRUIT (Hylocereus constaricensis) STEM CUTTINGS AS AFFECTED BY CONCENTRATIONS AND DIPPING TIMES OF COCONUT WATER]. Dragon fruits (Hylocereus constaricensis) is commonly propagated vegetatively by using stem cutting. In this respect, the use of natural plant growth regulator, such as coconut water, to promote the growth of the cuttings is critical. The objectives of this experiment were to evaluate water coconut concentration, dipping time of stem cutting in the coconut water, and the combination of both to promote the growth of dragon fruit cuttings. The experiment was arranged in a Randomized Complete Block Design with two factors and five replications. The first factor was the concentration of coconut water, consisting of 5 levels: $20,40,60,80$, and $100 \%$. The second factor was the dipping time of cutting in the coconut water, consisting of 4 levels: 2, 4, 6, and 8 minutes. The results showed that increasing coconut water concentration had linearly increased the shoot growth. A similar trend was also observed for coconut water dipping time. The highest shoot growth was found on $60 \%$ coconut water.
\end{abstract}

Keyword: coconute water, dragon fruit, vegetative

\begin{abstract}
ABSTRAK
Buah naga merupakan salah satu tanaman sejenis kaktus yang tergolong baru bagi masyarakat Indonesia. Tanaman ini sebagian besar diperbanyak secara vegetatif dengan menggunakan pemotongan batang. Penggunaan zat pengatur tumbuh tanaman alami, seperti air kelapa, untuk mendorong pertumbuhan stek sangat penting. Tujuan penelitian untuk mengevaluasi konsentrasi air kelapa, waktu perendaman pemotongan batang dalam air kelapa, dan kombinasi keduanya untuk meningkatkan pertumbuhan stek buah naga. Disain yang digunakan ialah Rancangan Acak Lengkap (RAL) yang terdiri atas dua faktor. Faktor pertama adalah lama perendaman air kelapa muda yaitu 2 jam, 4 jam, 6 jam, dan 8 jam. Faktor kedua adalah konsentrasi air kelapa muda yaitu 20, 40, 60, 80, dan 100\%. Media tanam yang digunakan yaitu tanah, abu, sekam dan pupuk kandang kambing dengan dimasukkan pada polibag berdiameter $15 \mathrm{~cm}$. Hasil penelitian menunjukkan bahwa peningkatan konsentrasi air kelapa muda memberikan respon linear positif untuk pertumbuhan stek batang tanaman buah naga merah. Kecenderung serupa juga dijumpai pada waktu pencelupan air kelapa muda. Pertumbuhan tunas tertinggi stek batang buah naga merah diperoleh pada konsentrasi air kelapa muda $60 \%$.
\end{abstract}

Kata kunci: air kelapa, buah naga, vegetatif 


\section{PENDAHULUAN}

Buah naga merupakan salah satu tanaman sejenis kaktus yang tergolong baru bagi masyarakat Indonesia. Buah ini cukup populer karena rasanya yang manis dan memiliki beragam manfaat untuk kesehatan. Buah ini merupakan hasil hutan yang sudah lama dimanfaatkan oleh orang Indian, tetapi selama itu tidak pernah diberitakan dalam media massa dunia (Winarsih, 2007 ).

Buah naga memiliki beragam jenis di antaranya buah naga berdaging putih, berdaging merah, dan berdaging kuning. Buah naga berdaging merah adalah buah yang paling disukai dibandingkan dengan lainnya karena rasanya yang manis dan warna daging buahnya yang menarik (Lutfia et al., 2018). Buah naga atau dragon fruit mempunyai kandungan zat bioaktif yang bermanfaat bagi tubuh di antaranya antioksidan (dalam asam askorbat, betakaroten, dan anthosianin), serta mengandung serat pangan dalam bentuk pektin. Selain itu, dalam buah naga terkandung beberapa mineral seperti kalsium, fosfor, besi, dan lain-lain. Vitamin yang terdapat di dalam buah naga antara lain vitamin B1, vitamin B2, vitamin B3, dan vitamin C (Oktaviani, 2014).

Permintaan buah naga saat ini cukup tinggi. Winarsih (2007) dan Nurfadilah et al. (2012) menyatakan bahwa kebutuhan buah naga di Indonesia mencapai 200 -400 ton/tahun. Kebutuhan buah naga yang besar tersebut belum mampu dipenuhi oleh produsen dalam negeri maupun negeri asal buah ini (Tim Karya Tani Mandiri, 2010). Oleh karena itu peluang untuk membudidayakan buah naga masih terbuka lebar baik untuk pasar lokal dan mancanegara.

Pengembangan dan penanaman buah naga di Indonesia masih terpusat pada beberapa daerah seperti pulau Jawa, Sumatra, dan Kalimantan. Buah naga dapat dikembangkan secara vegetatif dan generatif. Sistem perbanyakan secara vegetatif dan generatif mempunyai kelebihan dan kelemahannya masing-masing. Namun dalam praktiknya, orang lebih cenderung melakukan perbanyakan secara vegetatif. Perbanyakan secara vegetatif mempunyai beberapa masalah salah satunya stek bibit buah naga yang ditanam sering mati. Untuk mengatasi masalah tersebut diperlukan zat pengatur tumbuh yang dapat merangsang pertumbuhan akar stek pada buah naga.

Zat Pengatur Tumbuh (ZPT) yang sering digunakan untuk perakaran adalah auksin, namun relatif mahal dan sulit diperoleh (Muswita, 2011). Oleh karena itu diperlukan sumber ZPT lainnya yang mudah diperoleh dan relatif murah harganya, salah satunya air kelapa muda. Air kelapa muda banyak dimanfaatkan untuk kesegaran dan mengandung berbagai macam zat, termasuk di dalamnya hormon sitokinin dan auksin, vitamin $\mathrm{C}$, vitamin B, sedikit lemak, Ca dan P (Young et al., 2009 ; Yunita, 2011 ; Sitepu et al., 2015). Zat pengatur tumbuh yang terkandung dalam air kelapa merangsang selsel pada jaringan eksplan untuk membelah dan berdiferensiasi membentuk tunas (Karimah et al., 2013). Terpacunya pertumbuhan tunas mengakibatkan jumlah tunas yang terbentuk semakin banyak (Harjadinata, 2009). Hasil penelitian Rendani et al. (2015) menunjukkan bahwa penambahan tunggal air kelapa pada konsentrasi $20 \%$ mendorong munculnya tunas tercepat, yaitu 19,25 hari, jumlah tunas tertinggi dengan ratarata 6,83 tunas dan tunas terpanjang dengan rata-rata $3,30 \mathrm{~cm}$. Selain itu, hasil penelitian Sitepu et al. (2015) menunjukkan bahwa aplikasi air kelapa muda memberikan respons dalam meningkatkan pertumbuhan bibit setek tanaman buah naga yakni pada panjang tunas $30 \mathrm{hst}$, dan bobot kering tunas terberat dihasilkan oleh konsentrasi auksin $25 \%$. Respon positif tanaman terhadap aplikasi zat pengatur tumbuh dipengaruhi oleh beberapa faktor, di antaranya jenis tanaman, fase tumbuh tanaman, jenis zat pengatur tumbuh, konsentrasi dan cara aplikasi zat pengatur tumbuh (Saefas et al., 2017). Adanya pengaruh konsentrasi menyebabkan zat pengatur tumbuh perlu ditentukan konsentrasinya saat melakukan aplikasi pada tanaman. Penelitian ini bertujuan untuk mendapatkan konsentrasi air kelapa muda dan lama perendaman yang terbaik pada pertumbuhan stek batang buah naga merah (Hylocereus costaricensis).

\section{METODE PENELITIAN}

Penelitian ini telah dilaksanakan pada bulan Januari 2018 sampai April 2018 di Balai Benih Hortikultura Kabupaten Kepahiang. Disain yang digunakan ialah Rancangan Acak Lengkap (RAL) yang terdiri atas dua faktor. Faktor pertama adalah lama perendaman air kelapa muda yaitu 2, 4, 6, dan 8 jam. Faktor kedua adalah konsentrasi air kelapa muda yaitu 20 , 40, 60, 80, dan 100\%. Media tanam tanah, abu, sekam dan pupuk kandang kambing dengan perbandingan 1: $1: 1$ dimasukkan pada polibag berdiameter $15 \mathrm{~cm}$. Setiap perlakuan terdapat 4 sampel tanaman dan 3 kali ulangan sehingga terdapat 252 stek batang buah naga merah. Bahan stek diambil dari pohon induk tanaman buah naga merah di tempat penelitian yaitu Balai Benih Hortikultura Kabupaten Kepahiang. Panjang stek yang digunakan berukuran $30 \mathrm{~cm}$.

Data yang diperoleh dianalisis dengan uji $\mathrm{F}$ pada taraf 5\%. Untuk mendapatkan konsentrasi air kelapa muda dan lama perendaman yang terbaik pada pertumbuhan stek batang buah naga merah (Hylocereus costaricensis) dilakukan dengan menggunakan metode Polinomial Ortogonal (Yitnosumarto, 1990).

\section{HASIL DAN PEMBAHASAN}

Selama pelaksanaan penelitian perawatan yang dilakukan meliputi penyiraman, dan pembersihan gulma yang dianggap mengganggu. Gulma yang tumbuh di sekitar tanaman berupa gulma berdaun lebar dan berdaun sempit yang tidak diidentifikasi. Selama 
pertumbuhan stek, tidak ada penyakit yang menyerang tanaman buah naga.

Hasil analisis terhadap data yang dikumpulkan menunjukkan bahwa tidak terdapat interaksi $(\mathrm{P}>$ $0,05)$ antara lama perendaman air kelapa dan konsentrasi air kelapa muda terhadap pertumbuhan stek batang buah naga merah. Lama perendaman air kelapa hanya nyata pengaruhnya $(P \leq 0,05)$ terhadap tinggi tunas stek batang buah naga merah. Konsentrasi air kelapa muda nyata pengaruhnya $(\mathrm{P} \leq 0,05)$ terhadap tinggi tunas dan waktu tumbuh tunas stek batang buah naga merah.

Hubungan antara lama perendaman air kelapa dan tinggi tunas stek batang buah naga merah membentuk hubungan linear dengan persamaan garis $\mathrm{y}=$ $14,924+0,7085 x$ dengan nilai $\mathrm{R}^{2}=0,9807$ (Gambar $1)$.

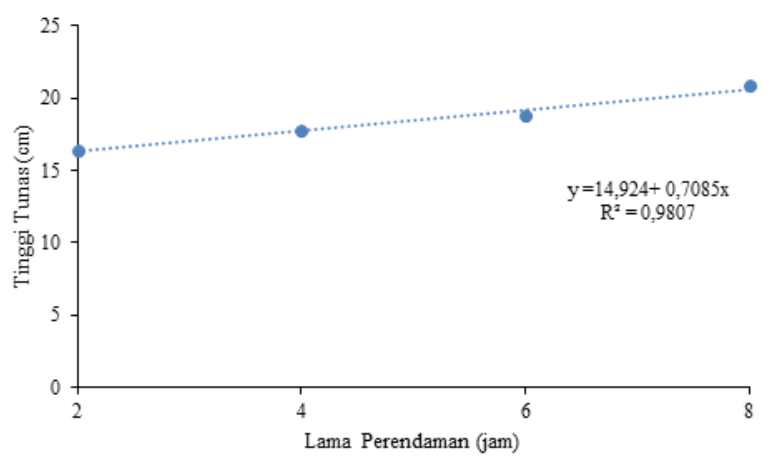

Gambar 1. Hubungan lama perendaman air kelapa dan tinggi tunas stek buah naga merah

Semakin lama perendaman air kelapa maka semakin meningkat tinggi tunas stek buah naga merah. Perendaman air kelapa selama 8 jam menghasilkan tinggi tunas stek buah naga merah tertinggi yaitu $20,82 \mathrm{~cm}$, sedangkan hasil terendah terdapat pada lama perendaman 2 jam yaitu $16,43 \mathrm{~cm}$. Hal ini diduga karena bahwa semakin lama perendaman air kelapa maka semakin banyak senyawa yang terkandung di dalam air kelapa yang terserap. Air kelapa mengandung sitokinin atau merupakan hormon pengganti sitokinin (Tuhuteru et al., 2012).

Secara umum hasil penelitian menunjukkan bahwa semakin lama perendaman air kelapa maka akan diikuti dengan semakin meningkat panjang akar, dan jumlah akar, namun waktu tumbuh tunas semakin cepat. Hal ini diduga semakin lama perendaman air kelapa maka kandungannya semakin banyak yang terserap. Waktu perendaman air kelapa yang singkat menyebabkan proses fisiologi pada tanaman tidak dapat berjalan dengan lancar mengakibatkan lambatnya pertumbuhan tanaman dan tinggi tanaman menjadi lebih rendah. Lingga dan Marsono (2004) menyatakan bahwa dengan bantuan zat pengatur tumbuh tanaman akan dapat menyerap hara melalui daun dan ditranslokasikan keseluruh bagian tubuh tumbuhan. Suriatna (1988) menyatakan bahwa apabila tanaman kekurangan unsur hara maka pertumbuhan tanaman akan terhambat dan kerdil. Air kelapa merupakan cairan yang mengandung unsur hara dan ZPT sehingga dapat menstimulasi perkecambahan dan pertumbuhan (Bey et al., 2006).

Konsentrasi air kelapa muda berpengaruh nyata terhadap tinggi tunas. Hubungan antara konsentrasi air kelapa muda dan tinggi tunas stek batang buah naga merah membentuk hubungan linear dengan persamaan garis $\mathrm{y}=13,182+0,0881 \mathrm{x}$ dengan nilai $\mathrm{R}^{2}=0,9412$ (Gambar 2).

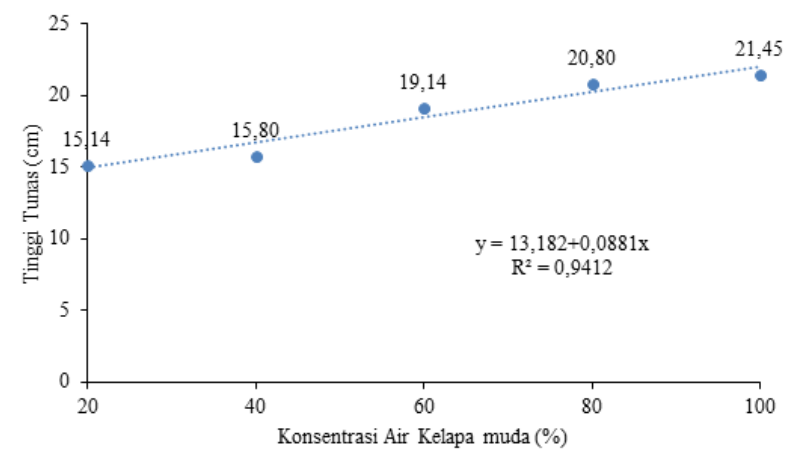

Gambar 2. Hubungan konsentrasi air kelapa muda dan tinggi tunas stek buah naga merah

Peningkatan konsentrasi air kelapa muda sampai dengan $100 \%$ diikuti dengan bertambahnya tinggi tunas stek buah naga merah. Hasil penelitian menunjukkan bahwa tinggi tunas pada perendaman air kelapa muda dengan konsentrasi $20 \%$ adalah sebesar $15,14 \mathrm{~cm}$. Selanjutnya terjadi peningkatan tinggi tunas pada pemberian konsentrasi $40 \%$ sampai $100 \%$ yaitu secara berturut-turut menjadi $15,80 \mathrm{~cm}, 19,14 \mathrm{~cm}, 20,80$ $\mathrm{cm}$, dan $21,45 \mathrm{~cm}$. Bertambahnya tinggi tunas pada setiap konsentrasi air kelapa muda diduga karena semakin tinggi konsentrasi yang diberikan mengakibatkan semakin banyak kandungan zat pengatur tumbuh, sehingga pertumbuhan stek semakin baik. Pemberian air kelapa pada konsentrasi $0-100 \%$ cenderung meningkatkan tinggi tunas rata-rata sebesar $2,46 \mathrm{~cm}$ pada pengamatan 30 hst, $15,79 \mathrm{~cm}$ pada $45 \mathrm{hst}$, dan $27,04 \mathrm{~cm}$ pada 60 hst (Sitorus et al., 2015). Pertumbuhan tunas dapat disebabkan oleh aktivitas meristem apikal yang lancar sehingga ketersediaan karbohidrat yang diperoleh digunakan untuk proses pembelahan sel.

Hubungan antara konsentrasi air kelapa muda dan waktu tumbuh tunas buah naga merah membentuk hubungan linear dengan persamaan garis $\mathrm{y}=$ $3,633+0,0033 \mathrm{x}$ dengan nilai $\mathrm{R}^{2}=0,3556$ (Gambar $3)$. 


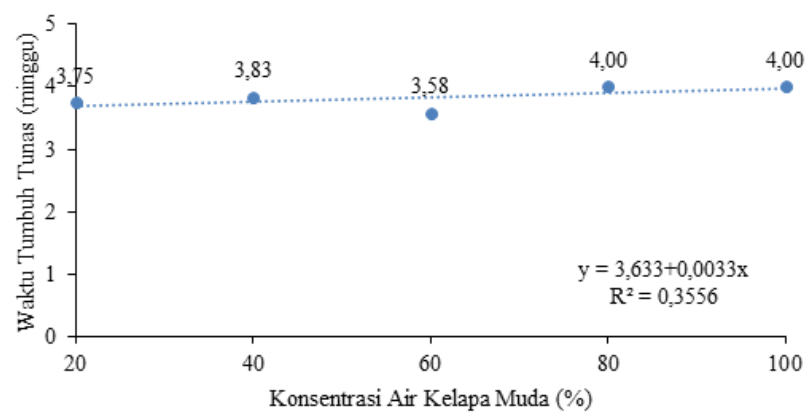

Gambar 3. Hubungan konsentrasi air kelapa muda dan waktu tumbuh tunas buah naga merah

Konsentrasi air kelapa 60\% menghasilkan waktu tumbuh tunas tercepat yaitu selama 3,58 minggu. Waktu tumbuh tunas terlama dihasilkan oleh pemberian air kelapa muda dengan konsentrasi $80 \%$ dan $100 \%$ yaitu selama 4,00 minggu. Secara umum peningkatan konsentrasi air kelapa justru menyebabkan waktu tumbuh tunas semakin lama. Hal ini diduga karena air kelapa muda mengandung senyawa fenolik berupa asam benzoik yang dapat menghambat pertumbuhan (Chairani, 1997). Senyawa fenolik tersebut dapat mengubah aktivitas hormon tanaman. Sebagaimana diketahui bahwa hormon ABA dapat menghambat proses transkripsi dan translasi dalam biosintesis protein. Dominasi ABA terhadap GA3 dan sitokinin mengakibatkan dormansi tetap berlangsung (Lakitan, 2007).

Air kelapa muda memiliki kandungan ZPT berupa giberelin, auksin dan sitokinin, sedangkan pada air kelapa tua kandungan hormon tersebut mereduksi seiring pematangan buah (Bey, 2005). Hormon tersebut dihentikan oleh asam benzoic yang berperan untuk menghentikan pertumbuhan. Penggunaan air kelapa sebagai zat pengatur tumbuh pada batas-batas tertentu mampu merangsang pertumbuhan, namun dapat bersifat sebagai penghambat apabila air kelapa telah matang atau tua. Perendaman pada larutan kelapa dengan konsentrasi $50 \%$ dapat memperpanjang masa dormansi biji (Ema \& Amalindah, 2009).

Secara umum hasil penelitian menunjukkan bahwa peningkatan konsentrasi air kelapa diikuti oleh peningkatan jumlah tunas, panjang akar dan jumlah akar. Hal ini diduga karena peran zat pengatur tumbuh yang terkandung dalam air kelapa. Air kelapa merupakan salah satu bahan alami yang mengandung hormon sitokinin 5,8 mg/L (Bey et al., 2006 ; Setiawan et al., 2013). Sitokinin berperan dalam meningkatkan pembelahan sel dan fungsi pengaturan pertumbuhan, serta perkembangan mata tunas dan pucuk (Harjadinata, 2009). Terdapat dua jenis sitokinin yaitu sitokinin alami dan sitokinin sintetik. Salah satu jenis sitokinin sintetik yang banyak digunakan yaitu Benzyl Amino Purine (BAP). Air kelapa mengandung berbagai jenis sitokinin alami yang dapat meningkatkan pembelahan sel dan merangsang pertumbuhan (Young et al., 2009). Kedua jenis sitokinin ini telah banyak digunakan sebagai bahan tambahan untuk multiplikasi nenas secara in vitro dan diharapkan mampu meningkatkan jumlah tunas yang terbentuk di lapang.

\section{KESIMPULAN}

Hasil penelitian menunjukkan perendaman air kelapa pada konsentrasi $100 \%$ menghasilkan tinggi tunas stek batang tanaman buah naga merah tertinggi yaitu $21,45 \mathrm{~cm}$. Konsentrasi air kelapa $60 \%$ menghasilkan waktu tumbuh tunas stek batang tanaman buah naga merah tercepat rata-rata 3,58 hari.

\section{DAFTAR PUSTAKA}

Bey, Y. (2005). Pengaruh pemberian Giberelin pada media Vacint dan Went terhadap perkecambahan biji Anggrek Bulan (Phalaenopsis amabilis BL) secara In Vitro. Biogenesis, 1(2), 57-61.

Bey, Y., Syafii, W. \& Sutrisna. (2006). Pengaruh pemberian Giberelin (GA3) dan air kelapa terhadap perkecambahan bahan biji Anggrek Bulan (Phalaenopsis amabilis $\mathrm{Bl}$ ) secara In Vitro. Biogenesis, 2(2), 4-46

Chairani, F. (1997). Pengaruh LarutanAir Kelapa terhadap PenurunanTunas Rimpang Jahe. Buletin Tanaman Rempah dan Obat (II) No.2. Balai Penelitian Tanaman Rempah dan Obat, Bogor.

Ema, A. \& Amalindah, D.V. (2009). Pengaruh Lama Perendaman Biji Kacang Hijau (Phaseolus vulgaris) dalam Air Kelapa Terhadap Kecepatan Perkecambahan. Laporan Penelitian. Universitas Negeri Malang, Malang.

Harjadinata, S.S. (2009). Zat Pengatur Tumbuh : Pengenalan dan Petunjuk Penggunaan pada Tanaman. Penebar Swadaya, Jakarta.

Karimah, A., Purwanti, S. \& Rogomulyo, R. (2013). Kajian perendaman rimpang Temulawak (Curcuma xanthorriza Roxb.) dalam urin sapi dan air kelapa untuk mempercepat pertunasan. VEGETALIKA, 2(2), 1-6.

Lakitan, B. (2007). Dasar-Dasar Fisiologi Tumbuhan. Raja Grafindo Persada, Jakarta.

Lingga, P. \& Marsono. (2004). Petunjuk penggunaan pupuk. Penebar Sawadaya. Jakarta.

Lutfia, U., Rugayah, R., Hendarto, K. \& Andalasari, T. D. (2018). Respons pertumbuhan setek batang buah naga merah (Hylocereus costaricensis) terhadap pemberian air kelapa.Jurnal Penelitian Pertanian Terapan, 17(3), 149-156.

Muswita. (2011). Pengaruh konsentrasi bawang merah (Alliumcepa L.) terhadap pertumbuhan setek gaharu (Aquilaria malaccencis OKEN). Jurnal Penelitian Universitas Jambi Seri Sain, 13(1), 15-20. 
Nurfadilah, Armaini \& Husna, Y. (2014). Pertumbuhan bibit buah naga (Hylocereus costaricensis) dengan perbedaan panjang stek dan konsentrasi zat pengatur tumbuh. JOM Fakultas Pertanian Universitas Riau, 1(1), 1-12.

Oktaviani, E. P. (2014). Kualitas dan Aktivitas Antioksidan Minuman Probiotik dengan Variasi Konsentrasi Ekstrak Buah Naga Merah (Hylocereus polyrhizus). (Doctoral dissertation, UAJY).

Rendani, B., Linda, R. \& Mukarlina. 2015. Pertumbuhan secara in vitro tunas Buah Naga Merah (Hylocereus polyrhizus [Weber] Britton \& Rose) dengan penambahan Naftalene Acetic Acid (NAA) dan air kelapa. J. PROTOBIONT, 4(3), 103-108.

Saefas, S. A., Rosniawaty, S., \& Maxiselly, Y. (2017). Pengaruh konsentrasi zat pengatur tumbuh alami dan sintetik terhadap pertumbuhan tanaman teh (Camellia sinensis (L.) O. Kuntze) Klon GMB 7 setelah Centering. Kultivasi, 16(2), 368-372.

Setiawan, P., Siagian, B., Ginting, J. \& Ginting, J. (2013). Pengaruh perendaman benih kakao dalam air kelapa dan pemberian pupuk NPKMg (15-15 -6-4) terhadap Pertumbuhan Bibit Kakao (Theobroma cacao L.). Jurnal Agroekoteknologi Universitas Sumatera Utara, 1(4), 1265-1276.

Sitepu .F.E.T., Sitorus .M.R. \& Irmansyah, T. (2015). Respons Pertumbuhan Bibit Setek Tanaman Buah Naga Merah (Hylocereus costaricencis (Web) Britton \& Ross) Terhadap Pemberian Auksin Alami dengan Berbagai Tingkat Konsentrasi. Program Studi Agroekoteknologi, Fakultas Pertanian, Universitas Sumatera Utara, Medan.
Sitorus, M.R., Irmansyah, T. \& Sitepu, F.E.T. (2015). Respon pertumbuhan bibit setek tanaman buah naga merah (Hylocereus costaricencis (Web) Britton \& Ross) terhadap pemberian auksin alami dengan berbagai tingkat konsentrasi. Jurnal Agroekoteknologi, 3(4), 1557-1565.

Suriatna, S. (1988). Media Penyuluhan Pertanian. Universitas Terbuka Press., Jakarta.

Tim Karya Tani Mandiri. (2010). Pedoman Bertanam Buah Naga. Nuansa Aulia, Bandung.

Tuhuteru, S., Hehanussa, M.L. \& Raharjo, S.H.T. (2012). Pertumbuhan dan perkembangan Anggrek Dendrobium anosmum pada media kultur in vitro dengan beberapa konsentrasi air kelapa. Agrologia, $1(1), 1-12$.

Winarsih, S. (2007). Mengenal dan Membudidayakan Buah Naga. Aneka Ilmu, Semarang.

Yitnosumarto, S. (1990). Percobaan: Perancangan, Analisis dan Interpretasinya. Gramedia Pustaka Utama, Jakarta.

Young, J.W.H., Liya Ge, Yan, F.N. \& Swee, N.T. (2009). The chemical compotition and biological properties of coconut ( Cocos nucifera L) water. Molecules, 14(1), 5244-5164.

Yunita, R. 2011. Pengaruh Pemberian Urine Sapi, Air kelapa muda, dan Rootone-F Terhadap Pertumbuhan Stek Tanaman Markisa (Passiflora edulis). Fakultas Pertanian, Universitas Andalas, Padang 